\title{
Effect of low concentrations of synthetic surfactants on polycyclic aromatic hydrocarbons (PAH) biodegradation
}

\author{
Ana Rodrigues $^{\mathrm{a}, \mathrm{b}, *}$, Regina Nogueira ${ }^{\mathrm{a}, \mathrm{d}}$, Luís F. Melo ${ }^{\mathrm{c}}$, António G. Brito ${ }^{\mathrm{a}}$ \\ ${ }^{a}$ Centre of Biological Engineering, Institute for Biotechnology and Bioengineering, University of Minho, Portugal \\ ${ }^{\mathrm{b}}$ School of Agriculture, Polytechnic Institute of Viana do Castelo, Portugal \\ ${ }^{c}$ LEPAE - Faculty of Engineering of the University of Porto, Chemical Engineering Department, 4200-465 Porto, Portugal \\ d Institute for Sanitary Engineering and Waste Management, Leibniz University Hannover, Welfengarten 1, D-30167 Hannover, Germany
}

\section{A R T I C L E I N F O}

\section{Article history:}

Received 6 November 2012

Received in revised form

31 March 2013

Accepted 2 April 2013

Available online 10 May 2013

\section{Keywords:}

$\mathrm{PAH}$

Fluoranthene

Anthracene

Biodegradation

Surfactant

Pseudomonas

\begin{abstract}
A B S T R A C T
The present study is focused on the effect of synthetic surfactants, at low concentration, on the kinetics of polycyclic aromatic hydrocarbons (PAH) biodegradation by Pseudomonas putida ATCC 17514 and addresses the specific issue of the effect of the surfactant on bacterial adhesion to $\mathrm{PAH}$, which is believed to be an important mechanism for the uptake of hydrophobic compounds. For that purpose, three surfactants were tested, namely, the nonionic Tween 20, the anionic sodium dodecyl sulphate (SDS) and the cationic surfactant cetyltrymethyl ammonium bromide (CTAB). Data showed that the effect of each surfactant on the ability of strain ATCC 17514 to biodegrade fluoranthene and anthracene and to use them as growth substrate varied considerably. Tween 20 , at a concentration of $0.08 \mathrm{mM}$, increased the biodegradation rate of fluoranthene and doubled the maximum specific biodegradation rate of anthracene. The presence of SDS, at a concentration of $0.35 \mathrm{mM}$, led to a reduction of $50 \%$ on the biodegradation rate of fluoranthene, but doubled the removal rate of the more hydrophobic anthracene $\left(0.3 \mathrm{mg} \mathrm{L}^{-1} \mathrm{~h}^{-1}\right)$. Finally, CTAB, at a concentration of $0.27 \mathrm{mM}$, had a negative effect on the biodegradation of both $\mathrm{PAH}$, leading to an abrupt decrease on the biomass growth.
\end{abstract}

(c) 2013 Elsevier Ltd. All rights reserved.

\section{Introduction}

Polycyclic aromatic hydrocarbons (PAHs) are organic contaminants of concern for human health and natural ecosystems due to their known carcinogenic and mutagenic properties (Enzmingher and Ahlert, 1987). Their low water solubility limits their availability to microorganisms, which is a potential problem for bioremediation processes. Surfactant-mediated biodegradation is a promising alternative because the presence of surfactants can increase the solubility of PAHs and hence potentially increase their bioavailability (Li and Chen, 2009). The surfactants assemble into micelles at the critical micelle concentration (CMC), and the interior of the micelles provides a hydrophobic environment to solubilise nonpolar compounds such as hydrocarbons (Guerin and Jones, 1988). Therefore, only concentrations above CMC enhance the mobility and apparent solubility of PAHs (Edwards et al., 1991). However, high surfactant

\footnotetext{
* Corresponding author. Escola Superior Agrária de Ponte de Lima, Instituto Politécnico de Viana do Castelo, Refóios, 4990-706 Ponte de Lima, Portugal. Tel.: +351 258909740 .

E-mail addresses: acrodrigues@esa.ipvc.pt (A. Rodrigues), nogueira@isah.unihannover.de (R. Nogueira), Imelo@fe.up.pt (L.F. Melo), agbrito@deb.uminho.pt (A.G. Brito).
}

concentrations may be not only toxic for microorganisms (Laha and Luthy, 1992), but they can also reduce the adhesion of bacteria to hydrophobic surfaces (Rosenberg and Rosenberg, 1995), in addition to the negative environmental impacts or costs of application. Thus, if adhesion plays an important role in bacterial PAH uptake, then the use of surfactants may not be beneficial.

The sorption of surfactants to bacteria and to interfaces can either enhance or inhibit adhesion, depending on the nature of the surfaces and the surfactant itself (Neu, 1996). Most investigations dealing with the effects of surfactants on bacterial mineralization of PAHs were based on the use of surfactant concentrations above their CMC (Guerin and Jones, 1988; Liu et al., 1995). However, because the sorption of a surfactant to surfaces depends on the free concentration of the surfactant in solution, modifications of surface properties, caused by the surfactant, are significant at concentrations below the CMC (Neu, 1996).

The present study focused on the effect of low concentrations of synthetic surfactants on the kinetics of PAH biodegradation and addressed the specific issue of the effect of the surfactant on bacterial adhesion, which is believed to be an important mechanism for the uptake of hydrophobic compounds (Wick et al., 2002). For that purpose, the effects of low concentrations of the non-ionic surfactant Tween 20, the anionic sodium dodecyl sulphate (SDS) 
and the cationic cetyltrimethyl ammonium bromide (CTAB) on the uptake of fluoranthene and anthracene by Pseudomonas putida ATCC 17514 were investigated.

\section{Materials and methods}

\subsection{Chemicals}

Fluoranthene (FLU, 99\% pure) was purchased from Aldrich Chemical Co (Milwaukee, Wis) and anthracene (ANT, 99\% pure) was purchased from Sigma Aldrich (Steinheim). Stock solutions of PAHs were prepared in acetone $\left(10 \mathrm{mg}_{\mathrm{FLU}} \mathrm{mL}^{-1}\right.$ and $\left.5 \mathrm{mg}_{\mathrm{ANT}} \mathrm{mL}^{-1}\right)$. The water-solubilities of fluoranthene and anthracene are approximately 0.26 and $0.07 \mathrm{mg} \mathrm{L}^{-1}$, respectively. Aqueous stock solutions $\left(5 \mathrm{~g} \mathrm{~L}^{-1}\right)$ of the surfactants Tween 20 (Merck), SDS (Riedel-deHäen), CTAB (Pronalys AR) and Tergitol NP-10 (Sigma Chemical Co.) were prepared in distilled water and sterilised by filtration though a filter paper with a porosity of $0.2 \mu \mathrm{m}$. The main characteristics of the surfactants used in the present study are depicted in Table 1.

\subsection{Bacterial strain and culture conditions}

P. putida ATCC 17514 NCIMB 10015 was first grown in O mineral medium with glucose $\left(2 \mathrm{~g} \mathrm{~L}^{-1}\right)$ for $24 \mathrm{~h}$, at $25^{\circ} \mathrm{C}$. The mineral medium contained, per liter of solution, $69.6 \mathrm{mg}$ of $\mathrm{CaCl}_{2} \cdot 2 \mathrm{H}_{2} \mathrm{O}, 8 \mathrm{mg}$ of $\mathrm{NaCl}, 103 \mathrm{mg}$ of $\mathrm{KNO}_{3}, 698 \mathrm{mg}$ of $\mathrm{NaNO}_{3}, 100 \mathrm{mg}$ of $\mathrm{MgSO}_{4} .7 \mathrm{H}_{2} \mathrm{O}$, $100 \mathrm{mg}$ of NTA, $2 \mathrm{mg}$ of $\mathrm{FeSO}_{4} .7 \mathrm{H}_{2} \mathrm{O}, 0.1 \mathrm{mg}$ of $\mathrm{ZnSO}_{4} .7 \mathrm{H}_{2} \mathrm{O}$, $0.043 \mathrm{mg}$ of $\mathrm{MnSO}_{4} .5 \mathrm{H}_{2} \mathrm{O}, 0.3 \mathrm{mg}$ of $\mathrm{H}_{3} \mathrm{BO}_{3}, 0.24 \mathrm{mg}$ of $\mathrm{CoSO}_{4} .7 \mathrm{H}_{2} \mathrm{O}$, $0.01 \mathrm{mg}$ of $\mathrm{CuSO}_{4} .5 \mathrm{H}_{2} \mathrm{O}, 0.02 \mathrm{mg}$ of $\mathrm{NiSO}_{4} .7 \mathrm{H}_{2} \mathrm{O}, 0.03 \mathrm{mg}$ of $\mathrm{NaMoO}_{4} \cdot 2 \mathrm{H}_{2} \mathrm{O}, 0.5 \mathrm{mg}$ of $\mathrm{Ca}(\mathrm{OH})_{2}, 5 \mathrm{mg}$ of EDTA, $544.4 \mathrm{mg}$ of $\mathrm{KH}_{2} \mathrm{PO}_{4}, 2148.9 \mathrm{mg}$ of $\mathrm{Na}_{2} \mathrm{HPO}_{4}$ and $30 \mathrm{mg}$ of $\left(\mathrm{NH}_{4}\right)_{2} \mathrm{SO}_{4}$. Subsequently, a $25-\mu \mathrm{L}$ aliquot of fluorene or phenanthrene in acetone (10 $\mathrm{mg} \mathrm{mL}^{-1}$ ) was added to the medium for enzyme induction. The cultures were then incubated for 7 days in the dark at $25^{\circ} \mathrm{C}$, with shaking at $150 \mathrm{rpm}$. P. putida was able to use fluoranthene or anthrecene as sole carbon and energy source for growth.

\subsection{Biodegradation assays}

Experiments to measure the removal rates and the partition coefficients of PAHs between the solid phase and the liquid phase were carried out in 250-mL Erlenmeyer flasks. PAH-containing medium was prepared by adding a 2-mL aliquot of acetonedissolved fluoranthene $\left(10 \mathrm{mg} \mathrm{mL}{ }^{-1}\right)$ or a $4-\mathrm{mL}$ aliquot of acetone-dissolved anthracene. The solvent was allowed to evaporate before the addition of $100 \mathrm{~mL}$ of sterile $\mathrm{O}$ mineral medium, corresponding to a final PAH content of $200 \mathrm{mg} \mathrm{L}^{-1}$, approximately. The concentrations of PAHs used in the present study were much higher than the PAH pure-compound aqueous solubility limit, so that the effect of surfactants on the degradation of solid PAHs by P. putida could be assessed. Surfactants were added from sterilized stock solutions. Tween 20 was tested at a concentration slightly higher than its CMC, $0.08 \mathrm{mM}$. On the contrary, the concentration of SDS and CTAB used in the experiments was below their CMC (0.35

Table 1

Chemical characteristics of the surfactants.

\begin{tabular}{|c|c|c|c|}
\hline Surfactant & Designation & Type & $\mathrm{CMC}^{\mathrm{a}}(\mathrm{mM})$ \\
\hline СТАВ & $\begin{array}{l}\text { Cetyltrymethyl ammonium } \\
\text { bromide }\end{array}$ & Cationic & 1 \\
\hline SDS & Sodium dodecyl sulphate & Anionic & 8.5 \\
\hline Tergitol NP-10 & Nonylphenol & Non-ionic & 0.12 \\
\hline Tween 20 & $\begin{array}{l}\text { Polyoxyethylene sorbitan } \\
\text { monolaurate }\end{array}$ & Non-ionic & 0.06 \\
\hline
\end{tabular}

${ }^{a}$ CMC: critical micelle concentration. and $0.27 \mathrm{mM}$, respectively) in order to avoid solubilizing the PAHs in micelles. The inoculum was a culture of P. putida ATCC 17514 pregrown on the respective PAHs (with an optical density at $540 \mathrm{~nm}\left(\mathrm{OD}_{540}\right)$ of 0.4$)$. The volume of the inoculum was $10 \%$ of the total liquid volume. After inoculation, the flasks were sealed with sterile silicone stoppers, from which a gas filter was suspended, and incubated in the dark, at $24{ }^{\circ} \mathrm{C}$ on a gyratory shaker at $150 \mathrm{rpm}$ for 10-15 days. Sterile uninoculated and autoclaved controls were included. A 2-mL aliquot of cell suspension was sampled at regular time intervals and its $\mathrm{OD}_{540}$ was determined as a measure for the density of cell suspensions, after carefully shaking the samples. The $\mathrm{OD}_{540}$ was measured in a UNICAM, HE $\lambda$ IOS $\gamma$ spectrophotometer (Cambridge, United Kingdom). Sterilised mineral medium containing the respective surfactant concentration was used as background. Due to their size $(0.2-0.5 \mathrm{~mm})$, PAH crystals sedimented quickly and did not interfere with the OD measurements. Volatile suspended solids (VSS) concentration was determined, following the procedure described in American Public Health Association (1989), and used as a measure of biomass concentration. The concentration of PAH in the samples was also determined.

\subsection{Activity tests}

P. putida cells were grown on fluoranthene or anthracene, as described for the biodegradation assays, collected during the log phase, washed with phosphate buffer $\mathrm{pH} 7(0.01 \mathrm{M})$ and resuspended in mineral medium at an optical density of 0.5. PAHcontaining medium was previously prepared with a $2-\mathrm{mL}$ aliquot of acetone-dissolved fluoranthene or anthracene $\left(10 \mathrm{mg} \mathrm{mL}^{-1}\right)$. The solvent was allowed to evaporate before the addition of $4 \mathrm{~mL}$ of sterile mineral medium, corresponding to a final PAH content of $5 \mathrm{mg} \mathrm{mL}^{-1}$.

The specific activity of $P$. putida was assessed by measurements of oxygen uptake rates using a Biological Oxygen Monitor (YSI model 5300). The effect of surfactants during fluoranthene or anthracene degradation by P. putida was assessed for three different concentrations of Tween 20, SDS, and Tergitol (100, 500 and $\left.1000 \mathrm{mg} \mathrm{L}^{-1}\right)$. The cationic surfactant CTAB was tested at a concentration of $100 \mathrm{mg} \mathrm{L}^{-1}$.

First, the $10 \mathrm{~mL}$ YSI chambers were filled with cell suspension. The suspension was mixed with a magnetic stirrer to overcome external mass transfer resistances. After $\mathrm{O}_{2}$ saturation, the chambers were sealed with a tightly fitting stopper and the endogeneous oxygen consumption was recorded continuously by using a YSI electrode. About $20 \mathrm{~min}$ after the beginning of the experiment, $200 \mu \mathrm{L}$ of fluoranthene or anthracene containing medium ( $5 \mathrm{mg} \mathrm{mL}^{-1}$ ) were added by a syringe through the stopper of the YSI chamber (100 mg L $\mathrm{m}^{-1}$, approximately) and the change in slope of the $\mathrm{O}_{2}$ consumption records was measured. Then, surfactant was added to the culture medium through the stopper of the YSI chamber, the oxygen depletion being continuously recorded.

The maximum cell activity with and without surfactant was calculated by the slopes of the oxygen depletion records. All assays were performed within an experimental period of $0.5-5 \mathrm{~h}$ and in each experiment, the VSS concentration was assessed, in order to obtain the maximum specific cell activity $\left(\mathrm{g}_{\mathrm{O}_{2}} \mathrm{~g}_{\mathrm{Vss}}{ }^{-1} \mathrm{~h}^{-1}\right)$.

\subsection{PAHs}

Each sample was extracted with 2 equal volumes of n-hexane. A centrifugation (16,000 $\mathrm{g}$ for $10 \mathrm{~min}$ ) was performed to separate aqueous and organic phases. PAHs in the hexane fraction were separated by reversed-phase high-pressure liquid chromatography (RP-HPLC) by using a KNAUER chromatograph, equipped with a KNAUER K-2500 UV-detector (254 nm). A LiChroCART ${ }^{\circledR}$ 250-4 
LiChrospher ${ }^{\circledR}$ PAH column was used for component separation. The compounds were eluted using a gradient of acetonitrile $(A)$ and water (0-10 min, 50\%A; $10-35 \mathrm{~min}, 100 \% \mathrm{~A})$, pumped at a flow-rate

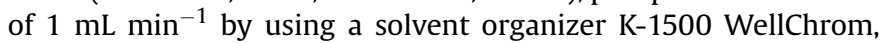
KNAUER and a HPLC pump K-1001, WellChrom, KNAUER. Total PAH concentrations were determined from a mixed liquor sample (containing mineral medium, cells, solid and dissolved PAHs). PAH in the solid phase (solid PAH and cell-associated PAH) and $\mathrm{PAH}$ concentration in the liquid phase (dissolved PAH and very small PAH crystals) were determined after centrifugation of the mixed liquor sample $(16,000 \mathrm{~g}$ for $10 \mathrm{~min})$. The supernatant was transferred to a sterile tube and the pellet was resuspended in $1 \mathrm{~mL}$ of mineral medium. For quantification of PAH in the solid phase, the sample was previously sonicated for $2 \mathrm{~min}$, in order to allow the desadsorption of cells from unsoluble PAH, being, afterwards, extracted with n-hexane.

\subsection{Cell surface properties}

Relative cell surface hydrophobicity determinations were carried out using a modification of the method described by Rosenberg et al. (1980). P. putida ATCC 17514 was grown in batch cultures, as described above, and harvested at the early stationary growth phase by centrifugation $(12,000 \mathrm{~g}, 10 \mathrm{~min})$. The pellet was washed and resuspended in mineral medium to an initial $\mathrm{OD}_{540}$ of 0.4 . The purity of the cultures was confirmed by plating on LB medium. A $4.5 \mathrm{~mL}$ portion of cell suspension $\left(\mathrm{OD}_{540}=0.4\right)$ was transferred to an acid-washed $(\mathrm{HCl}, 0.1 \mathrm{M})$ round-bottom glass tube, previously overlaid with $0.6 \mathrm{~mL}$ of hexadecane. Four test tubes were prepared following this procedure. Tween 20 was added to the first test tube to a concentration of $0.08 \mathrm{mM}, \mathrm{CTAB}$ was added to the second test tube to a concentration of $0.27 \mathrm{mM}$, and SDS was added to the third tube to a concentration of $0.35 \mathrm{mM}$. Surfactant was not added to the fourth tube, so that it could be used as control. This procedure was used for cells previously grown on either anthracene or fluoranthene. For each culture, a tube not overlaid with hexadecane was prepared. Blanks containing mineral medium with and without added surfactant were also prepared to account for hexadecane that came off the surface of the test tubes, which altered the measured $\mathrm{OD}_{540}$. Samples and controls were then vortexed for $60 \mathrm{~s}$. After an equilibration period of $10 \mathrm{~min}$, the loss in $\mathrm{OD}_{540}$ of the aqueous phase relative to that of the initial cell suspension was measured using a spectrophotometer UNICAM, HE $\lambda$ IOS $\gamma$. Hydrophobicity was estimated by calculating the percentage of cells adhering to hexadecane. The electric charge of $P$. putida cells grown on anthracene or fluoranthene, with and without added surfactant, was evaluated by zeta potential determinations. Measurements were performed with a micro-electrophoresis cell, Zetameter Inc. $3.0+$. The applied voltage was $200 \mathrm{~V}$, and each average value consisted of 25 records.

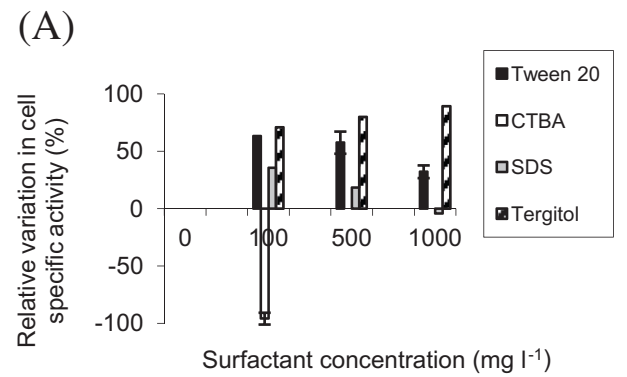

\section{Results}

\subsection{Cell activity versus surfactant dose}

Fig. 1 shows the results obtained in the activity tests, during P. putida growth on fluoranthene (A) or anthracene (B), in the presence of surfactants. The results show that, in the presence of the non-ionic surfactants Tween 20 and Tergitol NP-10, as well as in the presence of the anionic surfactant SDS, at a concentration of 100,500 and $1000 \mathrm{mg} \mathrm{L}^{-1}$, an increase in the oxygen uptake rate was observed during the utilization of fluoranthene or anthracene as substrate by $P$. putida cells, relatively to the results obtained in the absence of surfactant. On the other hand, the addition of the cationic surfactant CTAB, at a concentration of $100 \mathrm{mg} \mathrm{L}^{-1}$, had a toxic effect, leading to a sudden decrease in cell activity. Accordingly, no other CTAB concentration was tested. Moreover, a decrease in cell activity was sometimes observed, as a result of an increase in surfactant concentration (e.g., Tween 20).

\subsection{Effect of surfactants on PAH biodegradation kinetics}

According to the results obtained in the activity assays, the concentration of surfactant used in the biodegradation experiments was $100 \mathrm{mg} \mathrm{L}^{-1}$ since, in most of the cases, higher surfactant concentrations led to a decrease in cell activity (see, for instance, the results obtained for Tween 20 and SDS, in Fig. 1A). Therefore, the concentration of surfactant used in the biodegradation experiments corresponded to $0.08 \mathrm{mM}, 0.27 \mathrm{mM}$ and $0.35 \mathrm{mM}$, for Tween 20, CTAB and SDS, respectively. Thus, by using surfactant concentrations below the CMC, in the case of CTAB and SDS, and slightly higher than the CMC (differing in, approximately, $0.02 \mathrm{mM}$ ), as is the case of Tween 20 , it is possible to focus, in particular, on the effect of surfactants on bacterial adhesion. The results obtained in the biodegradation assays, in the presence and in the absence of surfactant, are depicted in Figs. 2-4, for Tween 20, CTAB and SDS, respectively. As can be observed in Fig. 2, Tween 20 had a stimulating effect on fluoranthene and anthracene mineralization by $P$. putida. Table 2 summarizes fluoranthene and anthracene biodegradation rates, in the presence and in the absence of Tween 20.

In the presence of $C T A B$, many cells adhered to the glass surface of the Erlenmeyer flasks, forming strong-yellow colonies. The results presented in Fig. 3 shows that CTAB inhibited the removal of PAHs from the culture medium. In fact, this surfactant had a negative effect on the uptake of PAHs in the solid phase (Fig. 3C). However, a fraction of PAH in the liquid phase was removed in the presence of the cationic surfactant (Fig. 3B), although at a much lower rate when compared to the one obtained in the absence of CTAB. In addition, the presence of CTAB in the medium reduced the adaptation period that was observed before the decrease in

(B)

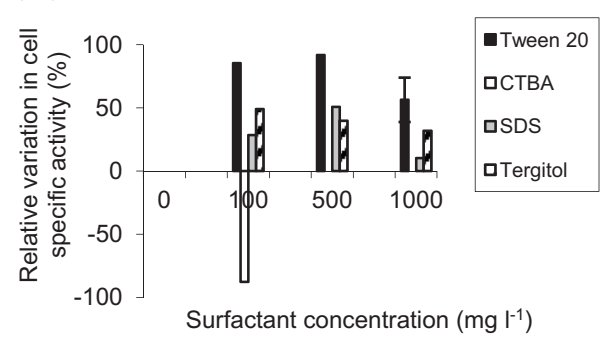

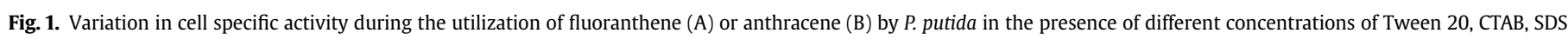
and Tergitol NP-10, relatively to cell activity in the absence of surfactant. 
(A)

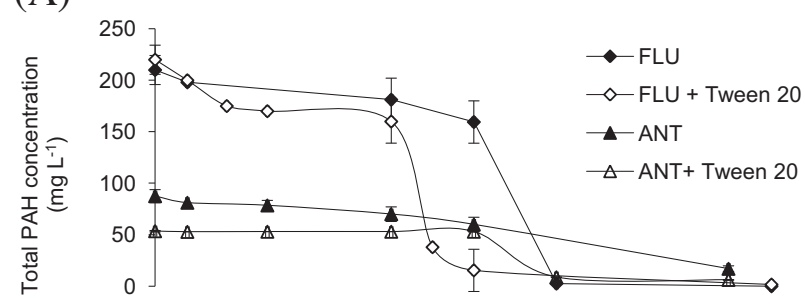

(B)

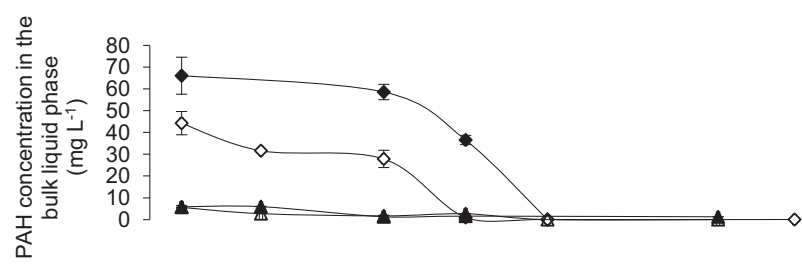

(C)

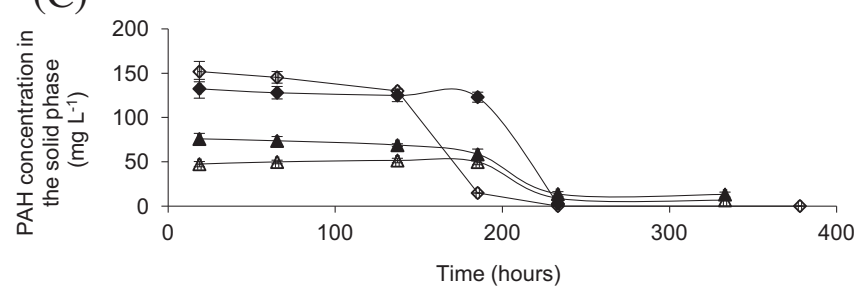

Fig. 2. Total PAH concentration (A), PAH concentration in the bulk liquid phase (B) and in the solid phase (C), during $P$. putida growth on fluoranthene (FLU) or anthracene (ANT) crystals, in the presence and in the absence of Tween $20(0.08 \mathrm{mM})$.

fluoranthene bulk liquid concentration. The results showed that the addition of SDS led to a decrease in the apparent overall removal rate of fluoranthene. However, in the case of anthracene, the presence of the anionic surfactant doubled its overall removal rate, when compared to the one detected in the absence of SDS (Fig. 4A). For fluoranthene and anthracene, the concentration of PAH in the solid phase considerably increased in the presence of the surfactant, as well as the PAH bulk liquid concentration, resulting in a complete removal of both PAHs. In Table 3, fluoranthene and anthracene biodegradation rates, in the presence and in the absence of SDS are depicted.

\subsection{Effect of surfactants on cell viability}

The effect of the surfactants on cell viability is presented in Fig. 5. Despite being able to degrade both PAHs (Figs. 2-4), P. putida ATCC 17514 was able to utilize anthracene as growth substrate, but not fluoranthene (Fig. 5), which was, apparently, used for cell maintenance or transformed in a sub-product.

The strain was also able to grow on the non-ionic surfactant Tween 20 (Fig. 5A). In fact, in the presence of fluoranthene and Tween 20, an exponential growth of the biomass was detected after an adaptation period of $50 \mathrm{~h}$ (Fig. 5A), whereas in the absence of surfactant only a linear growth could be observed. With anthracene, after $300 \mathrm{~h}$ of incubation, the cell density was identical with and without Tween 20. Nevertheless, despite the larger lag phase (of approximately $100 \mathrm{~h}$ ), the maximum growth rate was higher in the presence of Tween 20.

P. putida ATCC 17514 was also able to grow on the anionic surfactant SDS. Despite not being able to grow on fluoranthene as sole source of carbon, in the presence of SDS, an exponential growth

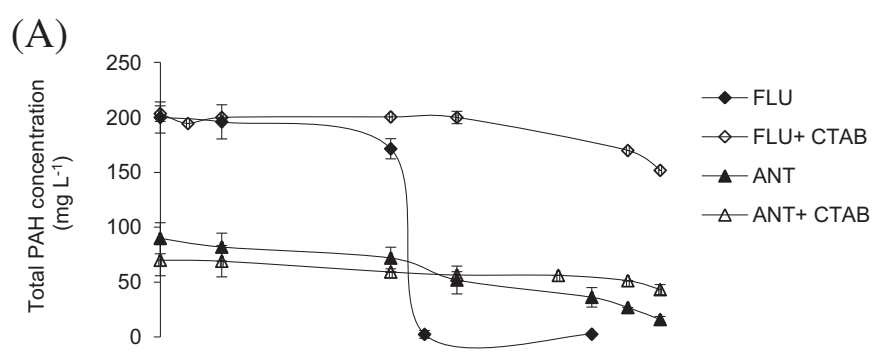

(B)

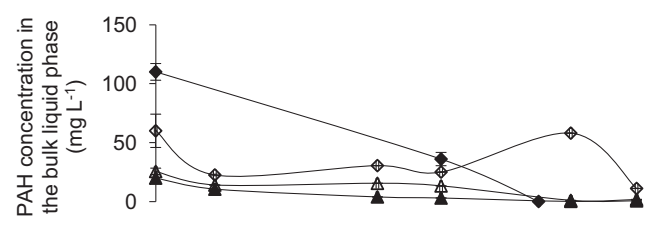

(C)

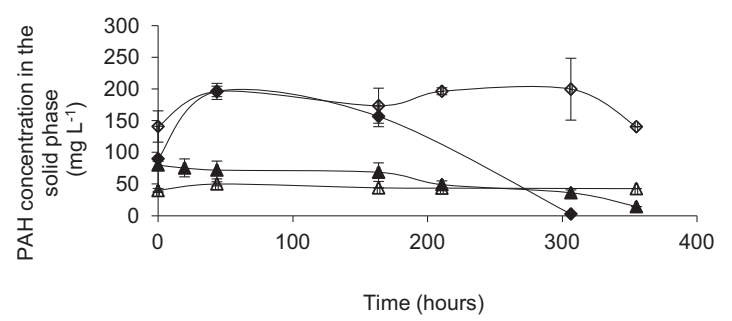

Fig. 3. Total $\mathrm{PAH}$ concentration (A), $\mathrm{PAH}$ concentration in the bulk liquid phase (B) and in the solid phase $(\mathrm{C})$, during $P$. putida growth on fluoranthene (FLU) or anthracene (ANT) crystals, in the presence and in the absence of CTAB $(0.27 \mathrm{mM})$.

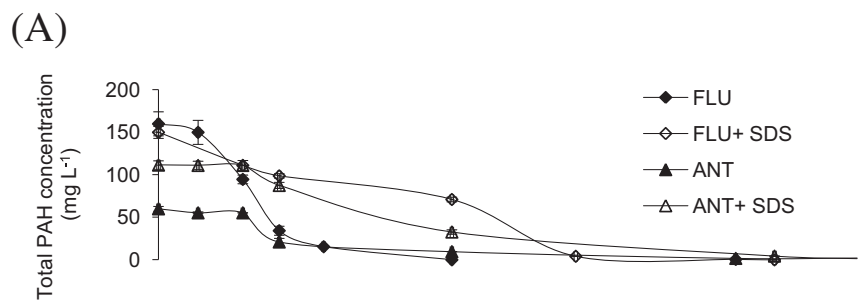

(B)

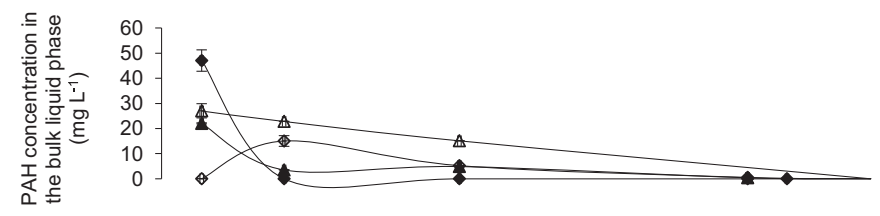

(C)

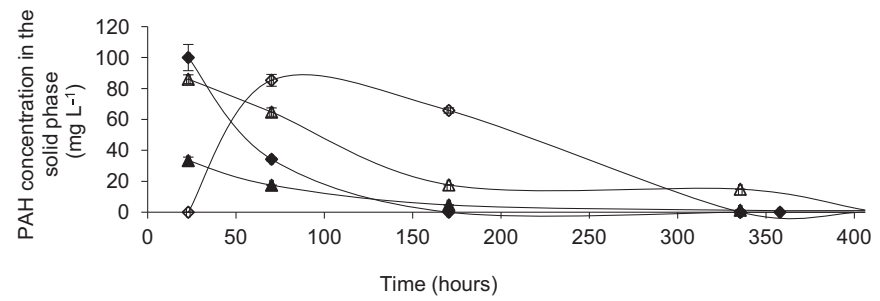

Fig. 4. Total PAH concentration (A), PAH concentration in the bulk liquid phase (B) and in the solid phase (C), during P. putida growth on fluoranthene (FLU) or anthracene (ANT) crystals, in the presence and in the absence of SDS $(0.35 \mathrm{mM})$. 
Table 2

Fluoranthene and anthracene removal rates with and without Tween 20 .

\begin{tabular}{|c|c|c|c|c|}
\hline Substrate & $\begin{array}{l}\text { Overall } \mathrm{PAH} \text { removal } \\
\text { rate }\left(\mathrm{mg} \mathrm{L}^{-1} \mathrm{~h}^{-1}\right)\end{array}$ & $\begin{array}{l}\text { Specific overall PAH } \\
\text { removal rate }\left(\mathrm{mg} \mathrm{g}_{\mathrm{VSS}}^{-1} \mathrm{~h}^{-1}\right)\end{array}$ & $\begin{array}{l}\text { Maximum observed removal rate } \\
\text { of PAH in the solid phase }\left(\mathrm{mg} \mathrm{L}^{-1} \mathrm{~h}^{-1}\right)\end{array}$ & $\begin{array}{l}\text { Maximum specific removal rate } \\
\text { of PAH in the solid phase }\left(\mathrm{mg} \mathrm{g}_{\mathrm{VSS}}^{-1} \mathrm{~h}^{-1}\right)\end{array}$ \\
\hline Fluoranthene & $0.27 \pm 0.03$ & $6.83 \pm 0.03$ & 2.40 & 62.82 \\
\hline Fluoranthene + Tween 20 & $1.10 \pm 0.23$ & $5.75 \pm 0.23$ & 2.51 & 12.50 \\
\hline Anthracene & $0.21 \pm 0.01$ & $0.62 \pm 0.01$ & 0.93 & 2.73 \\
\hline Anthracene + Tween 20 & $0.19 \pm 0.00$ & $1.16 \pm 0.00$ & 0.86 & 5.17 \\
\hline
\end{tabular}

was clearly observed, reaching high cell densities at the stationary growth phase (Fig. 5C). Moreover, the formation of cell aggregates was detected during degradation of fluoranthene in the presence of the anionic surfactant SDS. Conversely, in the presence of the cationic surfactant $\mathrm{CTAB}$, a continuous decrease in the biomass growth curve was observed (Fig. 5B).

\subsection{Effect of the surfactants on cell-surface properties}

After $P$. putida growth on fluoranthene or anthracene, with and without added surfactant, measurements of zeta potential and bacterial surface hydrophobicity were performed. The results obtained are presented in Table 4. Data indicate that cells grown in the presence of the non-ionic Tween 20 presented much lower zeta potential values than cells grown in the absence of surfactant. On the other hand, cell surface charge increased towards electroneutrality in the presence of the cationic and the anionic surfactants, CTAB and SDS, respectively. This result was more prevalent for the associations CTAB with fluoranthene and SDS with anthracene.

Regarding the relative hydrophobicity of $P$. putida cells, the results showed that the strain became less hydrophobic in the presence of surfactants. Indeed, a slight decrease in the percentage of cells adhered to the organic phase (hexadecane) was observed with the Tween 20 treatment, during growth on anthracene or fluoranthene. Concerning SDS or CTAB, the partition of cells to the hexadecane phase was totally inhibited by both surfactants.

\section{Discussion}

\subsection{Effect of the surfactants on cell activity}

Fig. 1 showed that the addition of the non-ionic surfactants Tween 20 and Tergitol NP-10, as well as the anionic surfactant SDS had, under the tested conditions, a positive effect on cell activity. An increase of $90 \%$ in the oxygen uptake rate could be observed during the biodegradation of anthracene in the presence of Tween 20 at a concentration of $500 \mathrm{mg} \mathrm{L}^{-1}$. On the contrary, the addition of the cationic surfactant CTAB, even at low concentrations $\left(100 \mathrm{mg} \mathrm{L}^{-1}\right.$, which is four times lower than its $(M C)$, led to a decrease of $88 \%$ in the oxygen uptake rate in the assay with anthracene, and $96 \%$ with fluoranthene. CTAB is a quaternary ammonium compound and binds by chemisorption to the cell surface of bacteria because the microbial cell surface at physiological $\mathrm{pH}$ is negatively charged. Thus, CTAB may inhibit bacterial adhesion to the substrate
(Campbell et al., 1999), which might be the reason for the observed decrease in cell activity, in the presence of CTAB.

The use of Tween 20 concentrations higher than $100 \mathrm{mg} \mathrm{L}^{-1}$ $(0.08 \mathrm{mM})$ did not induce a beneficial effect to the biodegradation of fluoranthene or anthracene. In fact, no significant changes in the specific oxygen uptake rate were observed when Tween 20 was added to the medium at a concentration of $500 \mathrm{mg} \mathrm{L}^{-1}$ and, at a concentration of $1000 \mathrm{mg} \mathrm{L}^{-1}$, a significant decrease of the positive effect of this surfactant on cell activity was observed. Moreover, the activity of $P$. putida cells during the degradation of fluoranthene or anthracene in the presence of Tween 20 concentrations of 500 and $1000 \mathrm{mg} \mathrm{L}^{-1}$ was lower than the one detected when Tween 20, at a concentration of $100 \mathrm{mg} \mathrm{L}^{-1}$, was used as sole carbon and energy source for growth $\left(0.46 \mathrm{~g}_{2} \mathrm{~g}_{\mathrm{vss}}{ }^{-1} \mathrm{~d}^{-1}\right)$. This result suggests that high concentrations of Tween 20 (higher than $500 \mathrm{mg} \mathrm{L}^{-1}$ ) may be toxic to microorganisms.

The addition of Tergitol NP-10 increased the oxygen uptake rate of $P$. putida cells during the degradation of either fluoranthene or anthracene. In the presence of fluoranthene, the beneficial effect of Tergitol NP-10, at a concentration of $100 \mathrm{mg} \mathrm{L}^{-1}$, was identical to the one obtained when the same concentration of Tween 20 was tested. However, unlike the trend observed with Tween 20, increasing concentrations of Tergitol NP-10 (500 and $\left.1000 \mathrm{mg} \mathrm{L}^{-1}\right)$ led to an increase in cell respiratory activity. This fact may be related to the higher capacity of utilization of Tween 20 as substrate by $P$. putida, when compared to Tergitol NP-10, and to a possible inhibitory effect at high concentrations of the former surfactant. Indeed, the cell activity in the presence of Tween $20\left(100 \mathrm{mg} \mathrm{L}^{-1}\right)$ as sole carbon and energy source for growth was $0.46 \mathrm{~g}_{\mathrm{O}_{2}} \mathrm{~g}_{\mathrm{vss}}{ }^{-1} \mathrm{~d}^{-1}$, whereas with Tergitol NP-10 (100 mg L ${ }^{-1}$ ) a value of only $0.08 \mathrm{~g}_{2} \mathrm{gvss}^{-1} \mathrm{~d}^{-1}$ was obtained, indicating the low biodegradability of the latter surfactant. During the utilization of anthracene as substrate by $P$. putida, the addition of Tergitol NP-10 increased the oxygen uptake rate, but not as much as Tween 20 increased it. The biodegradability of Tween 20 may also explain such result, suggesting that the observed enhancement in cell activity may be partially due to the metabolization of the surfactant itself. Preferential utilization of Tween 20 over pyrene by Mycobacterium sp. was also reported by Mahanty et al. (2008). Moreover, the higher increase in cell activity promoted by Tergitol NP-10 during the biodegradation of fluoranthene, when compared to anthracene, may be explained by the different physical properties of both PAHs. In fact, the lower water solubility of anthracene $\left(73 \mathrm{ppb}\right.$, at $\left.30^{\circ} \mathrm{C}\right)$ compared to fluoranthene $(260 \mathrm{ppb}$, at $30{ }^{\circ} \mathrm{C}$ ) may induce the utilization of different bacterial strategies to get access to such substrates (Rodrigues et al., 2005). In this case, the

Table 3

Fluoranthene and anthracene removal rates with and without SDS.

\begin{tabular}{|c|c|c|c|c|}
\hline Substrate & $\begin{array}{l}\text { Overall PAH removal } \\
\text { rate }\left(\mathrm{mg} \mathrm{L}^{-1} \mathrm{~h}^{-1}\right)\end{array}$ & $\begin{array}{l}\text { Specific overall PAH } \\
\text { removal rate }\left(\mathrm{mg} \mathrm{g}_{\mathrm{VSS}}^{-1} \mathrm{~h}^{-1}\right)\end{array}$ & $\begin{array}{l}\text { Maximum observed removal } \\
\text { rate of } \mathrm{PAH} \text { in the solid phase } \\
\left(\mathrm{mg} \mathrm{L}^{-1} \mathrm{~h}^{-1}\right)\end{array}$ & $\begin{array}{l}\text { Maximum specific removal } \\
\text { rate of PAH in the solid phase } \\
\left(\mathrm{mg} \mathrm{g}_{\mathrm{VSS}}^{-1} \mathrm{~h}^{-1}\right)\end{array}$ \\
\hline Fluoranthene & $0.94 \pm 0.08$ & $19.45 \pm 0.08$ & 1.39 & 28.89 \\
\hline Fluoranthene + SDS & $0.45 \pm 0.02$ & $1.18 \pm 0.02$ & 0.40 & 1.05 \\
\hline Anthracene & $0.17 \pm 0.01$ & $0.31 \pm 0.01$ & 0.34 & 0.61 \\
\hline Anthracene + SDS & $0.30 \pm 0.01$ & $0.61 \pm 0.01$ & 0.47 & 0.96 \\
\hline
\end{tabular}



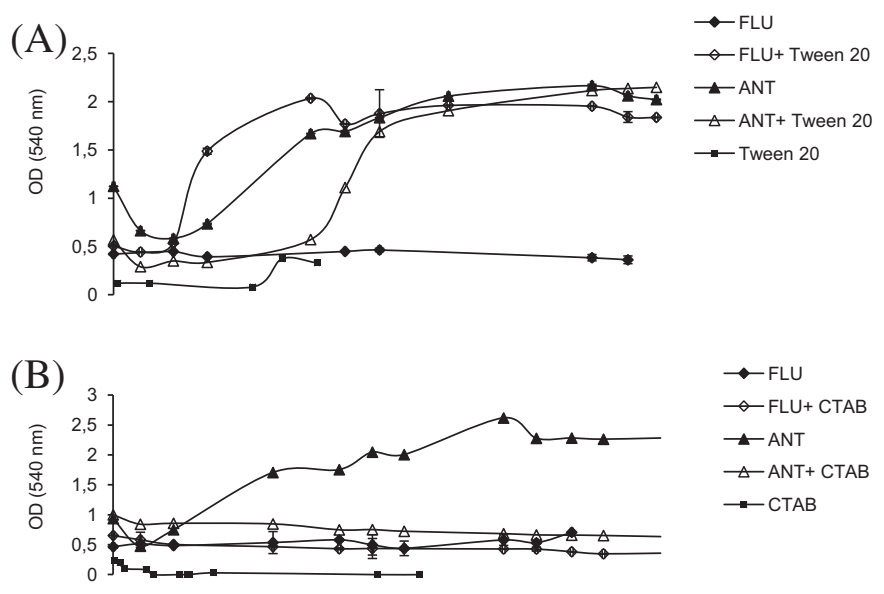

(C)

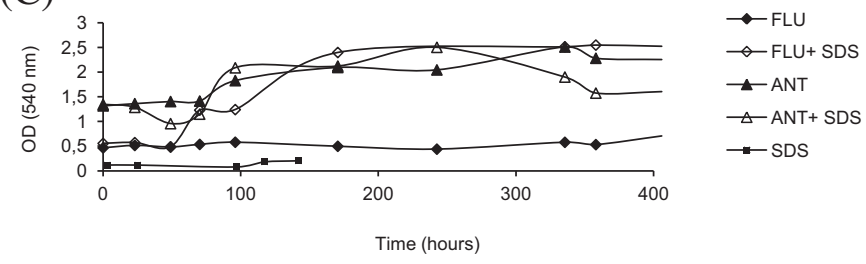

Fig. 5. Cell growth on fluoranthene or anthracene crystals, in the presence and in the absence of Tween 20 (A), CTAB (B) and SDS (C).

effect of the surfactant on cell activity will depend on the extent that the main mechanism for bacterial access to the substrate is affected.

Amendment with the anionic surfactant SDS also increased cell activity during the biodegradation of fluoranthene and anthracene, but not as much as the non-ionic surfactants Tween 20 and Tergitol NP-10 increased it. A positive effect was more noticeable when low concentrations of SDS were used, indicating a possible toxic or inhibitory effect in the presence of high surfactant concentrations.

\subsection{Effect of surfactants on PAH removal and cell survival}

\subsubsection{Effect of Tween 20}

The strain was able to grow on Tween 20 as carbon source, yet this did not affect the enhancing effect of Tween 20 on fluoranthene degradation. The surfactant enhanced the apparent biodegradation rate of the PAH in the liquid phase (Fig. 2B), resulting in an initial decrease in fluoranthene bulk liquid concentration, at a rate $\left(0.27 \mathrm{mg} \mathrm{L}^{-1} \mathrm{~h}^{-1}\right)$ higher than the one observed in the absence of surfactant $\left(0.06 \mathrm{mg} \mathrm{L}^{-1} \mathrm{~h}^{-1}\right)$. This fact can be explained by the increased bioavailability of fluoranthene dissolved in the micellar phase, since the concentration of Tween 20 used in these

Table 4

Cell-surface properties of Pseudomonas putida ATCC 17514 grown on fluoranthene or anthracene, with and without added surfactant.

\begin{tabular}{llc}
\hline Substrate & Zeta potential $(\mathrm{mV})$ & $\begin{array}{c}\text { Cells adhered to } \\
\text { hexadecane }(\%)\end{array}$ \\
\hline Fluoranthene & $-33.9 \pm 5.8$ & 13.8 \\
Fluoranthene + Tween 20 & $-91.0 \pm 22.5$ & 3.6 \\
Fluoranthene + CTAB & $-19.6 \pm 2.8$ & 0 \\
Fluoranthene + SDS & $-22.9 \pm 9.6$ & 0 \\
Anthracene & $-43.6 \pm 5.8$ & 15.7 \\
Anthracene + Tween 20 & $-87.7 \pm 23.2$ & 11.1 \\
Anthracene + CTAB & $-42.4 \pm 2.8$ & 0 \\
Anthracene + SDS & $-32.5 \pm 2.7$ & 0 \\
\hline
\end{tabular}

experiments $(0.08 \mathrm{mM})$ was slightly higher than its CMC $(0.06 \mathrm{mM})$. In all the experiments, the concentration of PAH in the solid phase was higher than the concentration of PAH in the bulk liquid phase. Either in the presence or in the absence of surfactant, after $18 \mathrm{~h}$ of incubation, $70 \%$ of the total fluoranthene corresponded to $\mathrm{PAH}$ in the solid phase, indicating that Tween 20, at a concentration slightly higher than its CMC, had no detrimental effect on the utilization of fluoranthene crystals by P. putida cells. Moreover, in the presence of Tween 20, the maximum apparent removal rate of fluoranthene in the solid phase slightly increased, reaching the value of $2.51 \mathrm{mg} \mathrm{L}^{-1} \mathrm{~h}^{-1}$. On the other hand, the maximum specific fluoranthene removal rate of fluoranthene in the solid phase decreased $80 \%$. This result is certainly due to the observed linear growth of the cells in the absence of surfactant (Fig. 5A), with a maximum biomass concentration of $74 \mathrm{mg}_{\mathrm{Vss}} \mathrm{L}^{-1}$, whereas in the presence of Tween 20, the cells grew exponentially reaching a biomass concentration of around $870 \mathrm{mgvss}^{-1}$. Therefore, the ratio of fluoranthene to biomass was higher in the absence of Tween 20, because cell density was lower in this case, the cells being saturated with this hydrophobic PAH. Yet, the overall fluoranthene removal rate increased $75 \%$ in the presence of the non-ionic surfactant.

Treatment with Tween 20 also had a beneficial effect on the removal of anthracene, doubling the maximum specific removal rate of anthracene in the solid phase $\left(5.17 \mathrm{mg} \mathrm{g}_{\mathrm{vss}}{ }^{-1} \mathrm{~h}^{-1}\right)$, as well as the overall specific removal rate $\left(1.16 \mathrm{mg} \mathrm{gvss}^{-1} \mathrm{~h}^{-1}\right)$. This result is consistent with the $85 \%$ increase in the oxygen uptake rate observed in the presence of the surfactant, during the degradation of anthracene by P. putida (Fig. 1B). Willumsen et al. (1998) obtained a similar result with Tween 80 , the addition of the non-ionic surfactant at a concentration three times higher than the one used in the present study $(0.24 \mathrm{mM})$ doubling fluoranthene mineralization rate by a Sphingomonas strain.

Aryal and Liakopoulou-Kyriakides (2013) also reported enhanced biodegradation of PAHs in the presence of Tween 20. The enhancing effect of Tween 20 on the biodegradation rate of fluoranthene was lower than the one observed for anthracene. A possible explanation for this phenomenon may be the lack of ability of $P$. putida to use fluoranthene as growth substrate. Consequently, in the presence of the biodegradable Tween 20, part of the surfactant will be consumed for cell growth, as can be observed in Fig. 5A. On the other hand, during growth on anthracene, the addition of the non-ionic surfactant increased the lag phase before the biomass exponential growth (Fig. 5A), reaching, however, the same values of cell density detected in the absence of surfactant.

\subsubsection{Effect of $C T A B$}

In the presence of CTAB, the concentration of PAH in the solid fraction was also higher than the concentration of $\mathrm{PAH}$ in the liquid phase. Nevertheless, the presence of the cationic surfactant inhibited the biodegradation of fluoranthene and anthracene in the solid phase (Fig. 3C), suggesting that the inhibitory effect of CTAB, at a concentration of $100 \mathrm{mg} \mathrm{L}^{-1}$, is probably related to the uptake mechanism of these PAHs. As previously mentioned, CTAB is a cationic surfactant that binds by chemisorption to the bacterial cell surfaces, due to the electrostatic attraction, preventing adhesion of the cells to the substrate (Neu, 1996; Campbell et al., 1999). Therefore, this result suggests that the direct contact between the bacterial cell and the PAH is a determinant factor to the uptake of such hydrophobic substrates. These observations are consistent with the results obtained in the activity assays (Fig. 1). In fact, when CTAB was added to the mineral medium, the cell activity rapidly decreased to

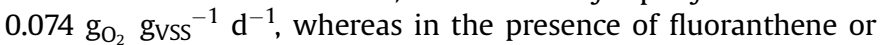
anthracene, amendment with CTAB immediately resulted in complete inhibition of the respiratory activity during, at least, the following $3 \mathrm{~h}$. Inhibition was accompanied by a continuous decrease 
in the biomass growth curve (Fig. 5B). Nevertheless, a fraction of the $\mathrm{PAH}$ in the liquid phase was removed in the presence of CTAB. Indeed, $P$. putida was able to use fluoranthene and anthracene present in the aqueous phase, after an adaptation period of $160 \mathrm{~h}$, approximately. The sudden decrease of the PAH bulk liquid concentration, initially observed, was probably due to the partitioning of PAHs to the biomass, or to the rapid uptake of the PAH dissolved in the aqueous phase, before the binding of CTAB to the whole cell surface. However, the maximum apparent degradation rate of fluoranthene in the liquid phase, after a long period of exposure of the cells to CTAB, was $0.12 \mathrm{mg} \mathrm{L}^{-1} \mathrm{~h}^{-1}$, a value that was five times lower than the observed degradation rate in the absence of surfactant.

After exposure to the cationic surfactant, the maximum degradation rate of anthracene in the supernatant decreased, reaching a value of $0.04 \mathrm{mg} \mathrm{L}^{-1} \mathrm{~h}^{-1}$. The utilization of fluoranthene and anthracene in the liquid phase by $P$. putida cells, after more than $160 \mathrm{~h}$ of exposure to CTAB, can be explained by an adaptation of some cells to the surfactant, at a concentration of $0.27 \mathrm{mM}$, four times lower than its CMC. Resistance of a Pseudomonas aeruginosa strain to quaternary ammonium compounds was already reported by Jones et al. (1989). Such tolerance may be correlated with changes of the outer membrane fatty acid composition. In fact, the observation of strong-yellow colonies of $P$. putida adhered to the glass surface of the Erlenmeyer flasks, in the presence of CTAB, can be explained by surfactant-induced permeabilization or lysis of the bacterial cell membrane of cells exposed to CTAB. The release of coloured products into the medium was also observed by Willumsen et al. (1998) due to cell-membrane-permeabilising capacity of Triton X-100, following growth of Sphingomonas and Mycobacterium strains on fluoranthene in the presence of this toxic, non-ionic surfactant, at a concentration above its CMC. In addition, as a result of the formation of bacterial colonies in the presence of fluoranthene or anthracene and CTAB, the cells present at the inner layers of the aggregates may have resisted to the toxic effect of the surfactant, being able to utilize the dissolved fraction of the PAH which penetrated into the cell aggregate. This kind of protection has been observed in other biological processes. For instance, in nitrification/denitrification processes, under aerobic conditions, the denitrifiers are usually located in inner anoxic niches, thus resisting to the inhibitory effect of oxygen and being able to utilize the nitrate that penetrates through the biomass flocs (Rodrigues et al., 2001).

\subsubsection{Effect of SDS}

The presence of SDS in the culture medium decreased the overall biodegradation rate of fluoranthene, from $0.94 \pm 0.08 \mathrm{mg} \mathrm{L}^{-1} \mathrm{~h}^{-1}$ to $0.45 \pm 0.02 \mathrm{mg} \mathrm{L}^{-1} \mathrm{~h}^{-1}$. A reduction of $96 \%$ in the specific degradation rate of fluoranthene in the solid phase (cell-associated and solid fluoranthene) was also detected after addition of the anionic surfactant, resulting in a maximum value of $1.05 \mathrm{mg} \mathrm{g}_{\mathrm{VSS}}^{-1} \mathrm{~h}^{-1}$. Alike for Tween 20 , this result may be explained by an exponential growth of the cells in the presence of fluoranthene with SDS, reaching a maximum biomass concentration of $1974.6 \pm 311 \mathrm{mg}_{\mathrm{vss}} \mathrm{L}^{-1}$ (Fig. 5C), whereas, without SDS, no cell growth was detected, the biomass concentration being $51.62 \pm 7.27 \mathrm{mg}_{\mathrm{vss}} \mathrm{L}^{-1}$. Besides, the concentration of fluoranthene in the liquid phase was higher in the presence of the anionic surfactant. This phenomenon may be the result of the observed reduction of the fluoranthene uptake rate, leading to a temporary accumulation of the PAH in the liquid phase.

As also described for the non-ionic surfactant Tween 20, the addition of SDS doubled the overall apparent removal rate of anthracene, resulting in a value of $0.30 \pm 0.01 \mathrm{mg} \mathrm{L}^{-1} \mathrm{~h}^{-1}$, as well as the maximum specific observed degradation rate of anthracene in the solid phase. This result does not appear to be consistent with the observations reported by Stelmack et al. (1999) during degradation of anthracene ( $500 \mathrm{mg} \mathrm{L}^{-1}$ ) by a Pseudomonas strain, in the presence of the anionic surfactant Dowfax 8390, at a concentration that was one-half its CMC. According to these authors, the presence of Dowfax 8390 resulted in a reduction in the uptake of the solid carbon source, indicating that the effect of the surfactant on PAH biodegradation is the result of a complex process which depends on the characteristics of the surfactant and the specific properties of the microorganisms involved. It is known that SDS inhibits hydrophobic interactions (Neu, 1996). Experiments performed with Streptococcus, revealed that hydrophobic bond-disrupting agents including SDS inhibited adhesion of the bacteria to hydroxylapatite (Nesbitt et al., 1982). Thus, if adhesion of cells to substrate is an important mechanism to PAH uptake, SDS may have a negative effect if adhesion is mainly due to hydrophobic interactions. On the other hand, Marchesi et al. (1991) found a correlation between SDS biodegradation and an increase of adhesion of a Pseudomonas strain to river sediments. These authors have demonstrated that during biodegradation, the bacterial cell surface became increasingly hydrophobic, a change which could be reversed by the removal of the primary intermediate of SDS biodegradation.

At the concentration used in the present study $(0.35 \mathrm{mM})$, the anionic surfactant SDS did not prevent partitioning of PAHs into bacterial cells (Fig. 4C), the cell-associated PAH concentration being higher than the concentration of PAH in the liquid phase, for both anthracene and fluoranthene. It is possible that, at a concentration that corresponds to $4 \%$ of its CMC, the negative effect of SDS on bacterial adhesion to hydrophobic PAHs would be insignificant. In addition, the concentration of fluoranthene and anthracene in the solid phase, in the presence of SDS, was higher than the one observed in the absence of the anionic surfactant (Fig. 4C). In the case of anthracene, the removal rate of the $\mathrm{PAH}$ in the supernatant was higher in the assays performed in the absence of $\operatorname{SDS}\left(0.4 \mathrm{mg} \mathrm{L}^{-1} \mathrm{~h}^{-1}\right)$. Similarly to Tween 20 , the beneficial effect of SDS was more intense during the biodegradation of anthracene, than that of fluoranthene. As previously mentioned, such result may be due to the biodegradability of SDS, which is used as co-substrate for cell growth during the utilization of fluoranthene by P. putida, as shown in Fig. 5C.

\subsection{Modification of the surface properties of P. putida by synthetic surfactants}

\subsubsection{Modification of the electric cell-surface charge}

The surface properties of cells exposed to carbon sources of different aqueous solubility (mineral medium amended with fluoranthene or anthracene), in the presence and in the absence of synthetic surfactants, were evaluated by means of zeta potential and electrophoretic mobility measurements. As already mentioned, CTAB is a cationic surfactant and, consequently, it binds to bacterial cell surfaces, due to the electrostatic attraction, influencing the zeta potential of the cells (Neu, 1996). In fact, after treatment with CTAB, at a concentration of $0.27 \mathrm{mM}$ (four times lower than its $\mathrm{CMC}$ ), the electric cell-surface charge presented a trend towards electroneutrality (Table 4). Accordingly, a reduction in the electrostatic repulsion between bacterial cells may occur. This fact was confirmed by the observed formation of cell aggregates during the utilization of fluoranthene or anthracene by $P$. putida, in the presence of CTAB, as previously referred. A similar result was obtained by Azeredo et al. (2002), after treatment of a culture of Pseudomonas fluorescens with CTAB, at a concentration of $0.5 \mathrm{mM}$. According to these authors, after the application of the cationic surfactant, cells became positively charged and remained adhered to a glass surface.

After the addition of anionic surfactant SDS, the zeta potential of the cells also tended towards electroneutrality, i.e., the electric cellsurface charge became less negative. A possible explanation for this phenomenon may be the production of polymeric substances or 
SDS degradation intermediates, which will induce changes in bacterial cell-surface properties and, consequently, the interactions between the cells and the PAH substrate will be affected. Such result also explains the formation of cell aggregates during the utilization of fluoranthene or anthracene by P. putida, in the presence of SDS, as a consequence of the reduction of the electrostatic repulsion.

Conversely, treatment with the non-ionic surfactant Tween 20 resulted in an increase in the electric cell-surface charge of $P$. putida to extremely high negative values. In this case, despite the high electrostatic repulsion expected to occur between highly negatively charged cells, partitioning of PAHs into the cells was not prevented by the surfactant.

\subsubsection{Hydrophobicity of cell surface}

The relative hydrophobicity was determined as the percentage of cells adhering to a hydrophobic phase (hexadecane). Cells grown on fluoranthene or anthracene showed a tendency to be less hydrophobic in the presence of the non-ionic Tween 20, than without the surfactant. On the other hand, the anionic and the cationic surfactants, SDS and CTAB, respectively, prevented bacterial partitioning into the hexadecane phase. Likewise, Azeredo et al. (2002) observed that, in the presence of CTAB, the cells became more hydrophilic, as a consequence of changes in the cell-surface properties, induced by the cationic surfactant, which explains the lack of affinity of the cells to hexadecane. After treatment with the anionic surfactant SDS, a decrease in cell surface polarity should be expected, since SDS anchors to the cell surface through its polar part, exposing the apolar part of the molecule (Azeredo et al., 2002). Yet, the results obtained in the hydrophobicity tests are not consistent with this observation, since cells did not show any affinity to the hexadecane phase after the application of SDS. Also, the addition of the non-ionic surfactant Tween 20 decreased the ability of the cells to adhere to the organic phase, especially when fluoranthene was used as substrate (Table 4). Curiously, the results obtained in the biodegradation experiments seem to indicate an opposite trend (Figss. 2 and 3, and 4). Indeed, the concentration of PAH in the solid phase was significantly higher than the concentration of PAH in the liquid fraction, even when SDS or CTAB were added to the culture medium, suggesting that partitioning of PAHs into the cells was not prevented, despite the alterations of the surface properties of cell walls induced by these surfactants. Unlike liquid hydrocarbons, such as hexadecane, fluoranthene and anthracene may be considered solid carbon sources and, therefore, a different bacterial behaviour could be expected during the utilization of these hydrophobic substrates, in the presence of synthetic surfactants.

\section{Conclusion}

The present study describes the effect of a non-ionic, an anionic and a cationic surfactant on the biodegradation of fluoranthene and anthracene by $P$. putida ATCC 17514. Therefore, it provides useful information to predict the environmental fate of these compounds and to develop practical PAH bioremediation strategies. The results obtained highlight that the biodegradation of crystalline fluoranthene and anthracene by P. putida ATCC 17514 can be stimulated by low concentrations of synthetic surfactants. However, it is very important to choose the correct combination between the microorganism, the PAH substrate and the surfactant molecule. In fact, it was shown that the same surfactant had different effects on the biodegradation of fluoranthene and anthracene by P. putida ATCC 17514.

The following conclusions can be drawn from the present study:

Treatment with the non-ionic surfactant Tween 20, at a concentration of $0.08 \mathrm{mM}$, led to an increase in the overall fluoranthene removal rate and doubled the overall specific removal rate of the more insoluble anthracene;

The presence of the anionic surfactant SDS, at a concentration of $0.35 \mathrm{mM}$, led to a reduction of approximately $50 \%$ in the overall fluoranthene removal rate, but doubled the overall degradation rate of the more hydrophobic anthracene, resulting in a value of $0.30 \mathrm{mg} \mathrm{L}^{-1} \mathrm{~h}^{-1}$;

The cationic surfactant CTAB, at a concentration of $0.27 \mathrm{mM}$, had a negative effect on the degradation rate of cell-associated PAH and, consequently, on the growth of $P$. putida when solid fluoranthene or anthracene was used as sole carbon source.

\section{References}

American Public Health Association (APHA), 1989. Standard Methods for the Examination of Water and Wastewater, seventeenth ed.. (Washington, D.C).

Aryal, M., Liakopoulou-Kyriakides, M., 2013. Biodegradation and kinetics of phenanthrene and pyrene in the presence of nonionic surfactants by Arthrobacter strain sphe3. Water, Air and Soil Pollution 224, 1426.

Azeredo, J., Pacheco, A.P., Lopes, I., Oliveira, R., Vieira, M.J., 2002. Monitoring cell detachment by surfactants in a parallel plate flow chamber. In: Proceedings of the International Specialised Conference on Biofilm Monitoring, Porto, Portugal, pp. 62-65.

Campbell, P., Srinivasan, R., Knoell, T., Phipps, D., Ishida, K., Safarik, T., Cormack, H. Ridway, H., 1999. Quantitative structure-activity relation (QSAR) analysis of surfactants influencing attachment of a Mycobacterium sp. to cellulose acetate and aromatic polyamide reverse osmosis membrane. Biotechnology and Bioengineering 64, 527-544.

Edwards, D.A., Luthy, R.G., Liu, Z., 1991. Solubilization of polycyclic aromatic hydrocarbons in micellar non-ionic surfactant solutions. Environmental Science and Technology 25, 127-133.

Enzmingher, J.D., Ahlert, R.C., 1987. Environmental fate of polynuclear aromatic hydrocarbons in coal tar. Environmental Technology Letters 8, 269-278.

Guerin, W.F., Jones, G.E., 1988. Mineralization of phenanthrene by a Mycobacterium sp. Applied and Environmental Microbiology 54, 937-944.

Jones, M.V., Herd, T.M., Christie, H.J., 1989. Resistance of Pseudomonas aeruginosa to amphoteric and quaternary ammonium biocides. Microbiology 58, 49-61.

Laha, S., Luthy, R.G., 1992. Effects of non-ionic surfactants on the solubilization and mineralization of phenanthrene in soil-water systems. Biotechnology and Bioengineering 40, 1367-1380.

Li, J.L., Chen, B.H., 2009. Surfactant-mediated biodegradation of polycyclic aromatic hydrocarbons. Materials 2, 76-94.

Liu, Z., Jacobson, A.M., Luthy, R.G., 1995. Biodegradation of naphthalene in aqueous non-ionic surfactant systems. Applied and Environmental Microbiology 61, 145-151.

Mahanty, B., Pakshirajan, K., Dasu, V.V., 2008. Synchronous fluorescence as a selective method for monitoring pyrene in biodegradation studies. Polycyclic Aromatic Compounds 28, 213-227.

Marchesi, J.R., Russel, N.J., White, G.F., House, W.A., 1991. Effects of surfactant adsorption and biodegradability on the distribution of bacteria between sediments and water in freshwater microcosm. Applied and Environmental Microbiology 57, 2507-2513.

Nesbitt, W.E., Doyle, R.J., Taylor, K.G., 1982. Hydrophobic interactions and the adherence of Streptococcus sanguis to hydroxylapatite. Infection and Immunity 38, 637-644.

Neu, T.R., 1996. Significance of bacterial surface-active compounds in interaction of bacteria with interfaces. Microbiological Reviews 60, 151-166.

Rodrigues, A.C., Brito, A.G., Melo, L.F., 2001. Post-treatment of a brewery wastewater using a Sequencing Batch Reactor. Water Environment Research 73, 45-51.

Rodrigues, A.C., Wuertz, S., Brito, A.G., Melo, L.F., 2005. Fluorene and phenanthrene uptake by Pseudomonas putida ATCC 17514: kinetics and physiological aspects. Biotechnology and Bioengineering 90, 281-289.

Rosenberg, M., Gutnic, D., Rosenberg, E., 1980. Adherence of bacteria to hydrocarbons: a simple method for measuring cell-surface hydrophobicity. FEMS, Microbiology Letters 9, 29-33.

Rosenberg, M., Rosenberg, E., 1995. Bacterial adherence at the hydrocarbon-water interface. Oil and Petrochemical Pollution 2, 155-162.

Stelmack, P.L., Gray, M.R., Pickard, M.A., 1999. Bacterial adhesion to soil contaminants in the presence of surfactants. Applied and Environmental Microbiology $65,163-168$.

Wick, L.Y., Munain, A.R., Springael, D., Harms, H., 2002. Responses of Mycobacterium sp. LB501T to the low bioavailability of solid anthracene. Applied Microbiology and Biotechnology 58, 378-385.

Willumsen, P.A., Karlson, U., Pritchard, P.H., 1998. Response of fluoranthenedegrading bacteria to surfactantes. Applied Microbiology and Biotechnology $50,475-483$. 